Stereozonography についての文献は少なくめ㞧り の例をみない，国内では渡辺らが肺門縦隔部へ応用し有 用であった旨報告している。われわれ性基礎的検討子終 り臨床応用について検討している，立体撮影に打ける管 球移動距離は FFD の約10〜15\%が良いと一般に言われ ている。断層装置は polytome U を使用しているのだ FFDは $143 \mathrm{~cm}$ となり振角を $6^{\circ} \sim 8^{\circ}$ にすると管球移動 距離が $11.5 \mathrm{~cm} \sim 15.4 \mathrm{~cm}$ に相当し FFDの $10 \%$ 前後と なる，又実際にフィルムマーク等を用いてテストした結 果で歹振角を $5^{\circ}$ 以下にすると立体感が搦いし，10以上 では強すぎて見ずらい。この方法で胸部縦隔，気管支造 影, 耳下腺造影, 脳血管撮影に応用乙非常に有用であった。

\section{7. 回転横断写真の画質の検討一透過線量を一定にし} て行う撮影一

鹿児島大学医学部附属病院放射線部

○小川臣人・池田睦・福島昇

豊浦 哲義・岡田 淳徳・下野、哲勇

頭部括よび胸部の回転横断撮影に肪いて，何れの回転 角度でる透過線量を一定にすべく，管電流を変化する方 法を試夕，この方法と通常の方法との画質の比較検討を 行った，各回転角度に設定する管電流值は次式より求め た. $\mathrm{mA} \theta=\mathrm{Rave} \cdot \mathrm{mA} / \mathrm{R} \theta こ こ て ゙ ， \mathrm{~mA} \theta$ は透過線量一 定法の管電流值， Rave は各角度に打㚈る透過線量の平 均值 $\mathrm{mA}$ 以管電流一定法の管電流值， $\mathrm{R} \theta$ は管電流一定 法の時の角度 $\theta$ に和ける透過線量である。

頭部では蝶形骨洞中隔，側頭骨岩様部などが，又胸部 では心臓周囲や縦隔部の描出で，管電流を変化させ透過 線量を一定にする方法が，従来の管管電流一定の方法に 優っており画質の向上がタうタられた。

\section{8. 平行移動断層装置を利用した矢状断層と横断断層}

千葉大学病院放射線部 伊場 昭三

平行移動断層装置のカセッテ支持台を取り，矢状断層 と横断断層を行ない撮影された断層像が臨床的に利用で きるかる検討した。断層惊等間隔に並べた金属線，紙パ イプ，腰椎，頭部ファントムを用い断層像の確認を行な った。この断層像を平面及びサーカス断層で得た断層像 そ比較した結果では今回の方法で撮影した断層像は像に 変形が女る事と解像の低下，晕像による偽断層陰影の現 われる事があるので臨床的にこの方法孝応用することは

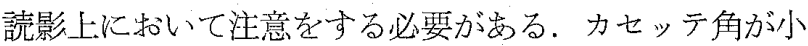
さい程コントラストも悪くフィルムの上下の濃度差も大 きく被曝線量も多くなる。
本演題群は断層撮影法に関する研究と, 他の撮影法の 併用時の研究であり，特にビームコントロールに関する 研究が多い，以下順を追って集約してみたい．

79 (達川他，佼成病院)性，縦隔及び肺絞理の断層で， 両者を同時に観察でさる写真の管電圧と付加フィルタの 適性範囲を求めている。これらの選択のみて胸郭内を 1 枚の写直に良く描出し得るかについては，80，81と関連 した可検域の問題であり，今後検討の余地がある 5 .

80 (岡山他, 山口大学) は, 脑門部全域の診断域の拡大 に，補償フィルタの必要性を指適し，実用的なフィルタ を報告した．後藤(兵庫)のフィルタの辺縁が写真上にで ないか。辺縁の角度決定は，固定法は。の質問に，答， 写真に影響ない，拡大率から求めた，ガイドレールとネ シ固定とした。

81 (佐藤他，千葉がんセンター) ほ，肺野濃度補償フィ ルタの報告で, 篠原 (東京)永ら研究発表の記載について 不備の指摘と，フィルタの厚さの決定法と基礎データの 求めに対し，(佐藤)フィルタの研究である。補足したい，

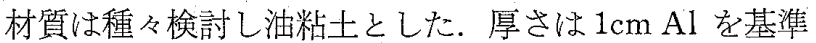
で 70〜90 kV で粘土は 3 倍必要, 図 6,7 は識别限界の データである。(岡山)はフィルタ愿さを縦隔部を濃度 1.0 に打いて求めている.

82 (梶原, 名古屋保健衛生大学) は, 可変饺り機構を利 用したスキップ断層で，被懪軽減を試みている．今後， 障害陰影を強く成立させる方向のスキップ操作の研究を 望名沈い.

83(米永他, 日本医大)は，傾斜截断の胆道系への使用 を報告した．特に総胆管末端部の断層像の改善に良いと しているが，截断の傾斜角度の設定に今後の研究課題が 女る。

84(山本他，三井記念病院)は，断層撮影装置の比較評 価の定義つけを目的に，MTF の取扱いで総合誤差の概 念を導さだし，装置の評価に有效な方法を提示した。

85(川野他, 名古屋市立大学) は, 多力向 X線管移動方 式の拡大断層をMTF 評価で求めた。東田(山口)から受 像系は. 軌道比較のレスポンスの逆転ばなぜか。截断面 レスポンスの違いの原因に装置精度とあるが，答，两面 を使用. 入射角度の違いが原因. 装置精度を従来の 2 倍 とした，佐藤(徳島)から，軌道の比較では截断の厚さを 一定にして行うべき，との指摘があった。

86(宇津見他，山口大学)は，ステレオゾノグラフィを 円軌道の曝射角度扁向法で行っている. 曝射角度扁向法 は19回学会で加藤他(関東労桨病院)が報告しているが， 立体視の観察の改善が今後普及のカギとなろう。

87 (小川他，鹿児島大)は，回転横断撮影でスキップ断

\title{
座長集約
}


層と全周断層との違いを，臨床例から比較検討している。 小川(東京)は，目的部に上り透過線量分布が異なり，一 概䫏部の補正カーブは描行ないのではないか，目的部 に合った透過線量分布の補正が必要ではないか。像の違 Wはごこに原因があるのか. 答, 目的部での線量分有の 補正が必要。基礎的検討はしなかった。松田らの文献を データとした。

88 (伊場，千葉大学) は, 平行移動型断層装置を利用し た矢状，横断では，㑇断層陰影が現われ臨床では無理が あるとしている、フィルムを垂面にたてる方法は，従来 から断層装置の精度や像の解析に用いられていたが，臨 床応用への警鐘となる報告である。

以上，簡単にまとめとしたが，研究の核心に心机る討 論があるりなされなかったのは，座長の不手際と時間の 制約が原因と思われ残念である. 本演題群でビームコン トロールに関する研究を忠つかったが，本来ビームコン トロールは撮影技術の中で大きなウェイトを占め，単独 のグループとして取り扱らべき性筫のるのと考党られる。 単独の演題群の設定で目的分明確化され研究の深まりと 現場技術の進歩が望める。

\section{感光材料-1}

來長 須長 祥浩（富士フィルム）

\section{SENSITOMETER の安定化とその試作回路につ} いて

\section{東海大学病院放射線科 \\ 古矢 義照・川又 郁夫・湯之上未已}

近年, 自現機が各施設にて数台導入され自現機管理に Sensitometer が使用されるよらにならた。この Sensitometer の必要条件はバラッキのない露光フィルムを得る ことであるが，我々の使用した Cronex Sensitometer は 黒化度 $25 \%$ 曰変化が女り, この原因学追求し性能検査 検討の上回路の改良を行ったところ，非常に安定した動 作が得られたので報告した。

\section{0. 静同県下 (中部地区)における使用カセッテの密着 性について}

静岡支部中部地区研究班

\begin{tabular}{|c|c|}
\hline 相㣮本 & 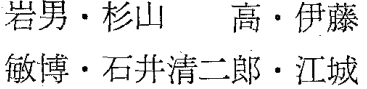 \\
\hline & 隆夫 · 村田 恒夫·吉川 \\
\hline & 正実 ·大久保善良 ·山来 \\
\hline & 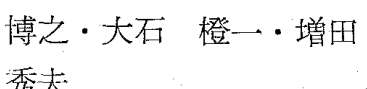 \\
\hline
\end{tabular}

[目的]静岡県下(中部地区) 36施設飞执いて日常使用 している，カセッテの密着性を取りあ声，アンケートを
含め調查検討を加光た。

[調查結果] 大角, 大随カセッテ 551 枚について調查 したが，大角サイズでは 211 枚中 130 枚 $61.7 \%$ ，大陸サ イズでは 340 枚中 248 枚 $73 \%$ に密着不良のある事がわ かった、密着不良個所の部分を $\mathrm{A}, \mathrm{B}, \mathrm{C}, \mathrm{D}, \mathrm{E}$ の 5 個所 に区分けし調查した結果では，C，Dのコーナーより $2 \mathrm{~cm}$ の範囲に压倒的に不良個所が出現していた，又不 良カセッテのMTFを測定し，不良個所活计る，頭部 ファントム X-P を技師数名にて視覚的評価したが，鮮 鋭度の覀い事を確認した。

〔まとめ〕カセッテの密着性は大事な問題で岕り，メ 一カーの努力と我々使用者のチェックが大切で离る.

\section{1. 乳房撮影におけるフィルムと増感紙の比較検討に ついて (その2)}

同愛記念病院放射線科

○高橋 重雄・虎渡 勇二・米道 成昭 小野公之・植木 邦雄・細川 明雄 新妻 邦雄

国産の希土類系X線フィルム，及び，スクリーンの專 用システムが開発されたので，従来の希土類系で最も優 れている Min- R システムと特性曲線, 相対感度, 及 び，CTF 觉比䫒検討したので報告する。

Min-R システムに比べ新しく国産で開発されたシス テムは，感度で $10 \%$ 高く, CTFに执いては， 2.5 本 $/ \mathrm{mm}$ で，8\%低下している。委た，との特性曲線は，非常に Min-R システム似ている。臨床上，Min-R システ ムと国産システムとで虫，棌とんど差がなく，X線フィ ルムのみで尃用のスクリーンを持たない場合より，やは り，專用システムの医らが，安定性などに捈いて優れて いるといらことがわかった。

92. マンモ用 RE スクリーン一フィルムシステムの特 性 大日本塗料・ 小田原 ○鈴木優二郎・四宮 患次 ·三浦 典夫 富士写真フィルム研究所 山田橴

新たな希土類蛍光体 $\left(\mathrm{Gd}_{2} \mathrm{O}_{2} \mathrm{~S}: \mathrm{Tb}\right)$ を用いた片面增感 紙と新タイプ微粒子片面乳剂オルソフィルムを組合せた 高感度で画質の優れた乳房撮影システムを開発した。

“本システムでは $\mathrm{Gd}_{2} \mathrm{O}_{2} \mathrm{~S}$ : Tb 䖢光体の軟 $\mathrm{X}$ 線領域に 特いても大きなX線吸収率と高いX線一光变換效率を利 用した片面增感紏々粒状を押觉た新タイプフィルムとの 組合せ汇よって，従来の $\mathrm{CaWO}_{4}$ 系システムと比較し て感度を $1.6 \sim 2.0$ 倍，鮮鋭度を $25 \%$ 向上することがで きた，更に低濃度部で高 $\gamma$ ，高濃部で低 $\gamma$ となるように 